\title{
Chronic Fos-Related Antigens: Stable Variants of $\Delta$ FosB Induced in Brain by Chronic Treatments
}

\author{
Jingshan Chen, ${ }^{1}$ Max B. Kelz, ${ }^{1}$ Bruce T. Hope, ${ }^{2}$ Yusaku Nakabeppu, ${ }^{3}$ and Eric J. Nestler ${ }^{1}$ \\ 1 Laboratory of Molecular Psychiatry, Departments of Psychiatry and Pharmacology, Yale University School of Medicine, \\ Connecticut Mental Health Center, New Haven, Connecticut 06508, ${ }^{2}$ National Institute of Mental Health, Bethesda, \\ Maryland 20892, and 3Kyushu University, Fukuoka 812, Japan
}

Fos family transcription factors are believed to play an important role in the transcriptional responses of the brain to a variety of stimuli. Previous studies have described 35 and $37 \mathrm{kDa}$ Fos-like proteins, termed chronic Fos-related antigens (FRAs), that are induced in brain in a region-specific manner in response to several chronic perturbations, including chronic electroconvulsive seizures, psychotropic drug treatments, and lesions. We show in this study that the chronic FRAs are isoforms of $\Delta \mathrm{FosB}$, a truncated splice variant of FosB that accumulate in brain after chronic treatments because of their stability. $\Delta$ FosB cDNA encodes the expression of 33,35 , and $37 \mathrm{kDa}$ proteins that arise from a single AUG translation start site. The 35 and 37 $\mathrm{kDa}$ proteins correspond to the chronic FRAs that are induced in brain by chronic treatments, whereas the $33 \mathrm{kDa}$ protein corresponds to a Fos-like protein that is induced in brain by acute treatments, findings based on migration on one- and two-dimensional Western blots with anti-FRA and anti-FosB antibodies. Using cells in which $\Delta$ FosB or FosB expression is under the control of a tetracycline-regulated gene expression system, we show that the $37 \mathrm{kDa} \Delta$ FosB protein exhibits a remarkably long half-life, the $35 \mathrm{kDa} \Delta \mathrm{FosB}$ protein exhibits an intermediate half-life, and the $33 \mathrm{kDa} \Delta$ FosB protein and all FosB-derived proteins exhibit relatively short half-lives. Moreover, we show that the $33 \mathrm{kDa} \Delta \mathrm{FosB}$ protein is the first to appear after activation of $\Delta$ FosB expression. Finally, $\Delta$ FosB proteins are shown to possess DNA-binding activity and to exert potent transactivating effects in reporter gene assays. Together, these findings support a scheme wherein $\Delta F o s B$, expressed as a $33 \mathrm{kDa}$ protein, is modified to form highly stable isoforms of 35 and $37 \mathrm{kDa}$. As a result, these stable isoforms gradually accumulate in the brain with repeated treatments to mediate forms of long-lasting neural and behavioral plasticity.

Key words: seizure; cocaine; FosB; chronic Fos-related antigens; gene expression; neural plasticity
Regulation of gene transcription is proposed to be an important mediator of long-term responses of the brain to chronic perturbations (Hyman and Nestler, 1996). One transcription factor that has received a great deal of attention for its potential role in these responses is activator protein-1 (AP-1) (Morgan and Curran, 1991, 1995). AP-1 is a dimer composed of various combinations of Fos- and Jun-like proteins. AP-1 complexes interact with AP-1 sites, with a consensus sequence of $\mathrm{TGA}(\mathrm{G} / \mathrm{C}) \mathrm{TCA}$, present in the promoter regions of target genes to increase or decrease the rate of the transcription of these genes.

There is now a large literature reporting that Fos- and Jun-like proteins are induced in brain, in a region-specific manner, in response to a wide variety of stimuli. Induction of these proteins, and the resulting AP-1 complex they form, is both rapid and transient. Consequently, these proteins could mediate some of the short-lived changes in gene expression elicited by these stimuli (Morgan and Curran, 1991). In contrast, work in several laboratories over the last few years has identified novel Fos-like proteins, termed chronic Fos-related antigens (FRAs), that are induced in brain in response to chronic perturbations and are much more

Received Feb. 7, 1997; revised April 3, 1997; accepted April 11, 1997.

This work was supported by United States Public Health Service Grants DA07359, MH51399, MH25642, and DA00203 (E.J.N.) and a gift from Johnson and Johnson (B.T.H.).

Correspondence should be addressed to Dr. Eric J. Nestler, Laboratory of Molecular Psychiatry, Departments of Psychiatry and Pharmacology, Yale University School of Medicine, Connecticut Mental Health Center, 34 Park Street, New Haven, CT 06508.

Copyright (C) 1997 Society for Neuroscience 0270-6474/97/174933-09\$05.00/0 long-lived than other Fos-like proteins induced acutely. These features make the chronic FRAs attractive candidates to mediate some of the longer-lasting transcriptional changes involved in the regulation of brain function (Hope et al., 1992, 1994a).

The chronic FRAs, identified as 35 and $37 \mathrm{kDa}$ proteins, are induced in specific brain regions in response to chronic, but not acute, administration of cocaine (Hope et al., 1994b; Nye et al., 1995; Moratalla et al., 1996), electroconvulsive seizures (ECSs) (Hope et al., 1994a), morphine (Nye and Nestler, 1996), nicotine (Pich et al., 1997), antipsychotic drugs (Nye et al., 1995), and antidepressant drugs (Hope et al., 1994b). The chronic FRAs also are induced after kainate lesions of the hippocampus and cortex (Pennypacker et al., 1994; Kasof et al., 1995) or 6-hydoxydopamine lesions of the striatum (Jian et al., 1993; Doucet et al., 1996). In each case, the chronic FRAs, once induced, are relatively stable proteins that persist in brain for long periods. For example, after a course of chronic cocaine or ECS administration, chronic FRAs remain detectable in striatum and frontal cortex, respectively, for at least 2 weeks. Similarly, in lesion paradigms the chronic FRAs remain detectable for several months.

The identity of the chronic FRAs has remained elusive despite considerable effort. The chronic FRAs are immunochemically related to $\Delta$ FosB, a truncated splice variant of FosB, but show different $M_{\mathrm{r}}$ values compared with $\Delta$ FosB-induced acutely in brain or cultured cells (Hope et al., 1994b; Chen et al., 1995, Doucet et al., 1996). These findings, coupled with the observation that levels of $\Delta$ FosB mRNA are not elevated at times when the chronic 
FRAs are induced (Chen et al., 1995; Pennypacker et al., 1995), have raised doubt as to whether the chronic FRAs are indeed $\Delta$ FosB-like proteins.

Despite this controversy, recent work has provided definitive evidence that the chronic FRAs are products of the fos $B$ gene. Induction of the chronic FRAs by repeated cocaine or ECS treatment is completely abolished in fos $B$ knock-out mice (Hiroi et al., 1996, 1997). However, this finding leaves unanswered the question of whether the chronic FRAs represent $\Delta$ FosB, shortened forms of FosB, or novel products of the fos $B$ gene. We show here, using an inducible expression system in vitro, that the chronic FRAs are, in fact, modified forms of $\Delta$ FosB that are highly stable proteins, which could account for their accumulation in brain in response to chronic perturbations.

\section{MATERIALS AND METHODS}

Construction of plasmids. FosB and $\triangle$ FosB cDNAs in pcDEBdelta vectors, under the control of a constitutive SR-alpha promoter (Nakabeppu et al., 1993), were placed under the control of an inducible promoter as follows. The FosB and $\triangle$ FosB cDNAs were subcloned into the pTet splice (Gibco/BRL, Gaithersburg, MD) by insertion of the SalI-BamHI fragment into the blunted SalI site of the pTet splice. The new plasmids were designated as pTetop-FosB and pTetop- $\Delta$ FosB. To place expression of the tetracycline transactivator (tTA) under the control of the neuronspecific enolase NSE promoter, we cloned the NSE promoter $(\sim 1.8 \mathrm{~kb})$ in pNSE-LacZ (a gift from Dr. J. Gregor Sutcliffe, Scripps) into pTettTAk (Gibco/BRL; the k denotes an added Kozak sequence to enhance translation) in place of the Tetop-minimal cytomegalovirus (CMV) promoter. The new plasmid was designated pNSE-tTAk, in which the HindII-XhoI fragment of pTet-tTAk was replaced by the HindII-SacI fragment of pNSE-LacZ.

There are four AUG codons in $\triangle$ FosB cDNA (Zerial et al., 1989; Nakabeppu and Nathans, 1991). To delete the first AUG, we removed the $H i n$ dII fragment of pcDEB- $\Delta$ FosB, and the plasmid was religated. The new plasmid was designated p-1AUG. To delete the first two AUGs, we removed the $B s t$ EII-EcoRV fragment of pcDEBdelta- $\Delta$ FosB, and the plasmid was religated and designated $\mathrm{p}-1,2 \mathrm{AUG}$.

The 4xAP-1/RSV-Luc construct (a gift from Dr. Steven Hyman, National Institute of Mental Health) consists of a promoter region of four consensus AP-1 sites, in tandem with a minimal RSV promoter, and a luciferase reporter gene under the control of this promoter.

Transfections. C6 glioma, SH-SY5Y (Biedler et al., 1978), and CATH.a (Suri et al., 1993) cells were cultured in DMEM with 5\% fetal bovine serum (FBS), DMEM with 10\% FBS, and RPMI 1640 with $8 \%$ horse serum plus $4 \%$ FBS, respectively. Transient transfections of the $\mathrm{SH}-$ SY5Y and CATH.a cells were performed by the calcium phosphate method. Approximately $75 \%$ confluent cultures in six-well plates were transfected with $10 \mu \mathrm{g}$ of plasmid DNA overnight and then washed with PBS (10 mM sodium phosphate, $\mathrm{pH} 7.4,150 \mathrm{~mm} \mathrm{NaCl})$ three times. The transfected cells were incubated in fresh medium for $24 \mathrm{hr}$, after which the cells were harvested for Western blotting or gel shift assays as described below. For luciferase reporter gene assays, the transfected cells were lysed by $1 \times$ reporter lysis buffer (Promega, Madison, WI). Relative luciferase activity, assayed as described in the luciferase assay protocol of Promega and measured in a luminometer, was calculated as enzyme activity per microgram of total protein (determined by Bradford assays).

For stable transfection, C6 glioma cells were transfected overnight, washed with PBS three times, and reincubated in fresh medium for $24 \mathrm{hr}$. The transfected cells were then split and incubated for another $24 \mathrm{hr}$. Stable C6 cell lines transfected with constitutive expression plasmids pcDEB- $\Delta$ FosB and pcDEB-FosB using the gene for hygromycin-B phosphotransferase (the hygromycin-B resistance gene) were selected by hygromycin $(100 \mu \mathrm{g} / \mathrm{ml})$. Stable C6 cell lines transfected with inducible expression plasmids pNSE-tTAk plus pTetop-FosB or pTetop- $\Delta$ FosB were selected by the neomycin resistance marker G418 (100 $\mu \mathrm{g} / \mathrm{ml})$ using cotransfection with a plasmid containing the gene for aminoglycoside phosphotransferase (the neomycin resistance gene).

In vivo ECS treatment. Male Sprague Dawley rats (initial weight, 140-260 g; Camm Research Institute, Wayne, NJ) were used for all experiments. An ECS was administered, as described previously (Hope et al., 1994a), via ear clip electrodes $(45 \mathrm{~mA}, 0.3 \mathrm{sec})$. Chronic animals received a single ECS daily for $10 \mathrm{~d}$. Control and acute animals received daily sham treatments, in which electrodes were clipped onto the ears of the rats, but no current was applied. On day 11, acute animals were given an acute ECS, and control and chronic animals were given sham treatment. Animals were killed $2 \mathrm{hr}$ later. Previous sham treatments were used in the control and acute animals to reduce the effects of stress (see Campeau et al., 1991; Sharp et al., 1991). Cerebral cortex was obtained by gross dissection.

Gel shift assays. Gel shift assays were performed as described previously (Hope et al., 1992, 1994a). The transfected cells $\left(\sim 5 \times 10^{7}\right)$ were lysed in $300 \mu \mathrm{l}$ of electrophoretic mobility shift assay (EMSA) buffer of Korner et al. (1989): $20 \mathrm{~mm}$ HEPES, pH 7.9, $0.4 \mathrm{~m} \mathrm{NaCl}, 20 \%$ glycerol, $5 \mathrm{~mm}$ $\mathrm{MgCl}_{2}, 0.5 \mathrm{~mm}$ EDTA, $0.1 \mathrm{~mm}$ EGTA, $1 \%$ Nonidet P- $40,10 \% \mu \mathrm{g} / \mathrm{ml}$ leupeptin, $0.1 \mathrm{~mm} p$-aminobenzamidine, $1 \mu \mathrm{g} / \mathrm{ml}$ pepstatin, $0.5 \mathrm{~mm}$ phenylmethylsulfonyl fluoride, and $5 \mathrm{~mm}$ dithiothreitol. Cerebral cortex was homogenized with Dounce homogenizers in 20 vol of the EMSA buffer. Crude homogenates were incubated on ice for $30 \mathrm{~min}$ before centrifugation at $15,000 \times g$ for $20 \mathrm{~min}$ at $4^{\circ} \mathrm{C}$. Aliquots of supernatants (containing $20 \mu \mathrm{g}$ of protein) were incubated at room temperature for $20 \mathrm{~min}$ with 1 $\mu \mathrm{g}$ of poly(dI-dC) poly(dI-dC), $40 \mu \mathrm{g}$ of bovine serum albumin, $10 \mathrm{~mm}$ Tris-HCl, pH 7.9, $10 \mathrm{~mm} \mathrm{KCl,} 1 \mathrm{~mm}$ EDTA, $4 \%$ glycerol, and $1 \mathrm{ng}$ of the radioactively labeled AP-1 probe derived from the AP- 1 site of the human metallothionein II gene (Hope et al., 1992). Then the samples were electrophoresed at $150 \mathrm{~V}$ for $2 \mathrm{hr}$ in a nondenaturing $6 \%$ acrylamide/ $0.16 \% N, N^{\prime}$-methylenebisacrylamide gel containing $25 \mathrm{~mm}$ Tris-borate buffer, pH 8.3, 1 mM EDTA, and $1.6 \%$ glycerol. The gels were dried and exposed to x-ray film. Levels of AP-1 binding were quantified by measuring the optical density of specific bands using an image analysis system with National Institutes of Health (NIH) image software.

Western blotting. One-dimensional Western blotting was performed as described previously (Hope et al., 1994a). Transfected cells and cerebral cortex were homogenized in EMSA buffer as described above for gel shift assays. Aliquots (containing $50 \mu \mathrm{g}$ of protein) were then applied to a $10 \%$ acrylamide/0.27\% $N, N^{\prime}$-methylenebisacrylamide resolving gel for SDSPAGE overnight at $75 \mathrm{~V}$ and then electrotransferred to nitrocellulose at $200 \mathrm{~mA}$ for $3 \mathrm{hr}$. The blots were blocked with four $15 \mathrm{~min}$ changes of $2 \%$ (for anti-FRA antibody; kindly provided by Dr. Michael Iadarola, National Institute of Dental Research, NIH) or $0.5 \%$ (for anti-FosB antibodies; see Chen et al., 1995) nonfat dry milk in PBS-Tween (PBS containing $0.1 \%$ Tween 20 ). The blots were then incubated overnight on a shaker at $4^{\circ} \mathrm{C}$ in a $1: 4000$ dilution of anti-FRA antibody or a 1:1000 dilution of anti-FosB antibodies in blocking buffer with $0.05 \%$ sodium azide. The blots were washed four times for $15 \mathrm{~min}$ each in blocking buffer and incubated for $2 \mathrm{hr}$ in a 1:4000 dilution of goat anti-rabbit antibody conjugated to horseradish peroxidase (Vector Laboratories, Burlingame, CA) in blocking buffer. The blots were washed eight times for $15 \mathrm{~min}$ each with PBS-Tween alone, developed with the enhanced chemiluminescence (ECL) system of Amersham (Arlington Heights, IL), and exposed to Hyperfilm-ECL (Amersham) for 5-60 sec. Levels of FRA immunoreactivity were quantified either by measuring the optical density of specific bands using an image analysis system or by measuring light intensity using the Bio-Rad (Hercules, CA) GS-363 phosphor-imager.

For two-dimensional Western blotting, samples (containing $225 \mu \mathrm{g}$ of protein) were separated by isoelectric focusing in tube gels for the first dimension according to published procedures (Hope et al., 1994b). The resulting tube gels were then layered across SDS-polyacrylamide slab gels (10\% acrylamide/ $0.4 \%$ bisacrylamide) and electrophoresed in the second dimension. The proteins in the resulting gels were transferred onto nitrocellulose membranes, and Western blotting was performed as described above.

\section{RESULTS}

\section{The 35 and $37 \mathrm{kDa}$ chronic FRAs are products of $\triangle$ FosB mRNA}

As stated in the introductory remarks, the 35 and $37 \mathrm{kDa}$ chronic FRAs can be recognized by anti-FosB antibodies but can be distinguished from FosB $(\sim 46 \mathrm{kDa})$ and $\Delta$ FosB $(\sim 33 \mathrm{kDa})$ on one-dimensional gels (Hope et al., 1994b; Chen et al., 1995). One possible explanation is that the chronic FRAs are proteolytic products of FosB. To test this possibility, we established stable C6 glioma cell lines constitutively expressing FosB or $\Delta$ FosB and analyzed proteins generated from the cell lines by Western blotting using a pan-FRA antibody (Fig. 1). Extracts of cerebral cortex 


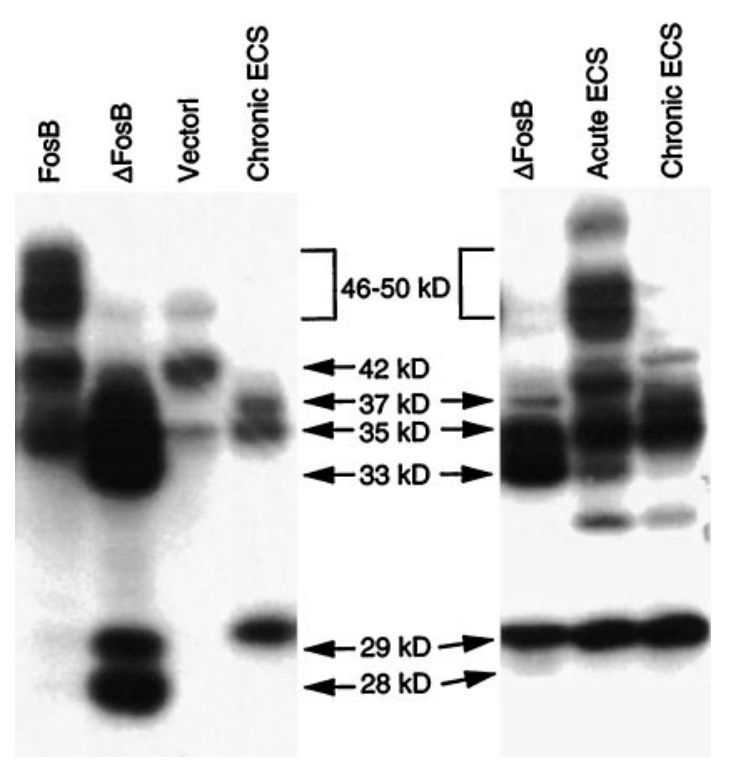

Figure 1. Western blots showing expression of FosB- and $\Delta$ FosB-derived proteins in stably transfected C6 glioma cells (left) and in transiently transfected Cath.a cells (right). Cells constitutively expressing FosB or $\Delta$ FosB cDNA were prepared. Cell extracts of these lines and of nontransfected cells (vector) were analyzed by Western blotting using the pan-FRA antibody (see Materials and Methods), which recognizes a domain conserved in all Fos-like proteins. Aliquots of cerebral cortex from rats treated acutely or chronically with ECS were analyzed for comparison. In both types of cells, FosB cDNA encodes the expression of proteins at $46-50$ and $35 \mathrm{kDa}$. $\triangle$ FosB cDNA encodes the expression of proteins at 37 , $35,33,29$, and $28 \mathrm{kDa}$. The 35 and $37 \mathrm{kDa} \Delta$ FosB-encoded proteins comigrate with the 35 and $37 \mathrm{kDa}$ chronic FRAs induced by chronic ECS treatment. The $33 \mathrm{kDa} \Delta$ FosB-encoded protein comigrates with the 33 $\mathrm{kDa}$ acute FRA induced by acute ECS treatment. The 29 and $28 \mathrm{kDa}$ $\Delta$ FosB-encoded proteins do not correspond to FRAs detected in the brain; they are distinct from an $\sim 30 \mathrm{kDa}$ protein seen in the chronic ECS sample that is constitutive and not regulated by ECS treatment. Note that a prominent $\sim 42 \mathrm{kDa}$ protein (possibly FRA-1 or -2 ) is present in control C6 cells (vector1) and in the FosB transfectants but is not in the $\Delta$ FosB transfectants. Note also that an $\sim 40 \mathrm{kDa}$ protein (possibly FRA-1 or -2 ) is induced in cortex by acute ECS treatment only. The results shown are representative of at least four separate determinations. All of the bands recognized by the anti-FRA antibody represent specific labeling, because detection was abolished by preincubation of the antibody with the immunizing peptide antigen (see Hope et al., 1994a).

from rats treated chronically with ECSs were analyzed for comparison. FosB-transfected cells expressed FRA-immunoreactive proteins in the $M_{\mathrm{r}}$ range of $46-50 \mathrm{kDa}$, which is consistent with the reported $M_{\mathrm{r}}$ of FosB (Zerial et al., 1989; Nakabeppu and Nathans, 1991). The cells also expressed lower levels of FRAs in the $M_{\mathrm{r}}$ range of $35 \mathrm{kDa}$. Although the $35 \mathrm{kDa}$ band comigrated with the $35 \mathrm{kDa}$ chronic FRA, no $37 \mathrm{kDa}$ chronic FRA-like band was generated by FosB cDNA.

$\Delta$ FosB-transfected cells expressed high levels of five FRAs with $M_{\mathrm{r}}$ values of $37,35,33,29$, and $28 \mathrm{kDa}$ (Fig. 1). The 35 and $37 \mathrm{kDa}$ $\Delta$ FosB-derived proteins migrated at the same position as the 35 and $37 \mathrm{kDa}$ chronic FRAs. The $33 \mathrm{kDa} \Delta$ FosB-derived protein migrated at the same position as a FRA induced by acute ECS (Fig. 1) or acute cocaine treatment (see Chen et al., 1995). In contrast, the 29 and $28 \mathrm{kDa} \Delta$ FosB-derived proteins did not correspond to FRAs detected in the brain.

Whereas a $37 \mathrm{kDa}$ FRA was generated by only $\triangle$ FosB cDNA, a $35 \mathrm{kDa} F R A$ was generated by both $\Delta$ FosB and FosB cDNA. To characterize the protein products from FosB- and $\Delta$ FosBtransfected cells further, we used antibodies selective for the $\mathrm{N}$
A

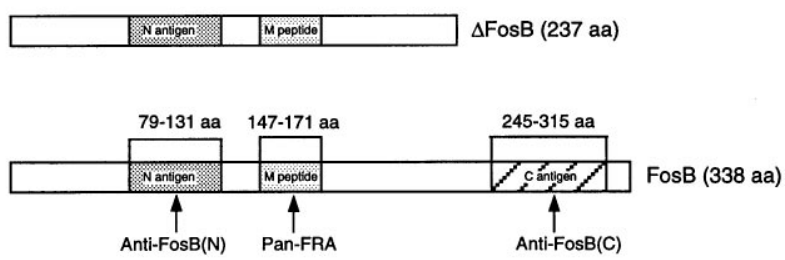

B
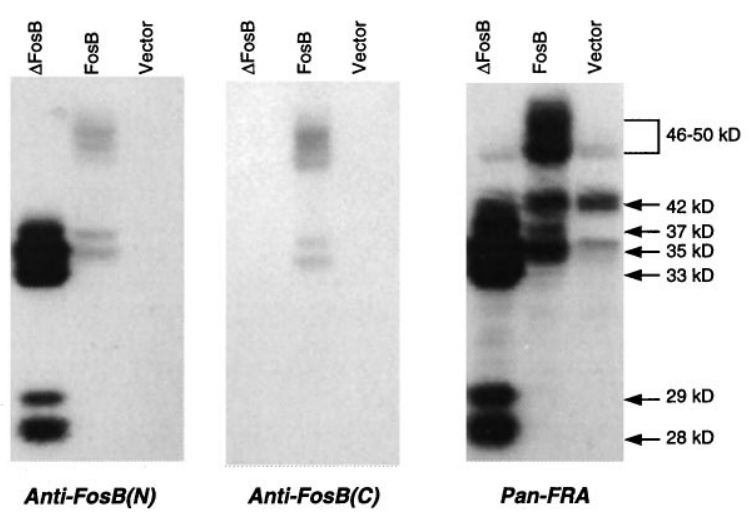

Figure 2. Western blots showing the expression of FosB- and $\Delta$ FosBderived proteins in stably transfected C6 glioma cells. $A$, Regions of the $\Delta \mathrm{FosB}$ and FosB proteins against which the anti-FosB(N), anti-FosB $(\mathrm{C})$, and pan-FRA antibodies are directed. $B$, Extracts of stable cell lines (see Fig. 1) that allow constitutive expression of FosB or $\triangle$ FosB cDNA or extracts of nontransfected cells (Vector), analyzed by Western blotting using an antibody directed against the $\mathrm{N}$ terminus of FosB [anti-FosB(N)], an antibody directed against the $\mathrm{C}$ terminus of FosB [anti-FosB(C)], or the pan-FRA antibody. Note that all of the $\Delta$ FosB-derived proteins were recognized by the anti-FosB(N) antibody but not by the anti-FosB $(\mathrm{C})$ antibody, whereas the FosB-derived proteins were recognized by both antibodies. Note also that none of the several proteins expressed in control cells and recognized by the pan-FRA antibody were recognized by the anti-FosB antibodies. The results shown are representative of three separate determinations.

terminus [anti-FosB(N)] or the $\mathrm{C}$ terminus [anti-FosB(C)] of FosB to distinguish $\Delta$ FosB- from FosB-derived proteins. This is based on the fact that $\Delta$ FosB lacks the $\mathrm{C}$ terminus of FosB and is therefore recognized by only the anti-FosB(N) antibody, whereas FosB is recognized by both antibodies. As shown in Figure 2, all five of the $\Delta$ FosB-derived proteins were recognized by anti$\operatorname{FosB}(\mathrm{N})$ but not by anti-FosB(C), which confirms that these proteins were generated from $\Delta$ FosB cDNA. In contrast, all of the FosB-derived proteins were recognized by both anti-FosB(N) and anti-FosB(C) antibodies. Because the 35 and $37 \mathrm{kDa}$ chronic FRAs are recognized only by the anti-FosB(N) antibody (Hope et al., 1994b; Chen et al., 1995), the results suggest that the $\sim 35 \mathrm{kDa}$ proteins in the FosB-transfected cells are not alternatively spliced $\Delta$ FosB products and are distinct from the chronic FRAs. Rather, these proteins would seem to be the same as the $35 \mathrm{kDa}$ FRAs induced in the brain by acute ECS or cocaine treatment (Chen et al., 1995).

To confirm that the chronic FRAs are $\Delta$ FosB-derived proteins, two-dimensional Western blotting was used to compare the chronic FRAs induced in the brain by chronic ECS treatment with the $\Delta$ FosB proteins expressed in cell culture (Fig. 3). Two cell culture systems were analyzed: transiently transfected CATH.a cells, in which the 35 and $33 \mathrm{kDa} \Delta$ FosB proteins predominate, and stably transfected C6 glioma cells, in which the $37 \mathrm{kDa} \Delta \mathrm{FosB}$ protein is expressed as well. The results of these experiments show 
Figure 3. Two-dimensional Western blots showing the expression of chronic FRAs in the brain and of $\Delta$ FosB-derived proteins in cultured cells. $A$, CATH.a cells transiently transfected with $\Delta$ FosB cDNA. $B$, Aliquots of cerebral cortex from rats treated chronically with ECSs, showing the migration of the 35 and $37 \mathrm{kDa}$ chronic FRAs as demonstrated previously (Hope et al., 1994a; Chen et al., 1995). C, C6 glioma cells stably transfected with $\Delta$ FosB cDNA. Cell and brain extracts were analyzed by twodimensional Western blotting using the pan-FRA antibody. The figure shows the comigration of the $37 \mathrm{kDa} \Delta$ FosB with the $37 \mathrm{kDa}$ chronic FRA and of the 35 $\mathrm{kDa} \Delta$ FosB with the $35 \mathrm{kDa}$ chronic FRA. The $33 \mathrm{kDa} \Delta$ FosB comigrates with a $33 \mathrm{kDa}$ FRA induced in the brain by an acute ECS treatment (see Chen et al., 1995). The results shown are representative of two to three separate determinations.

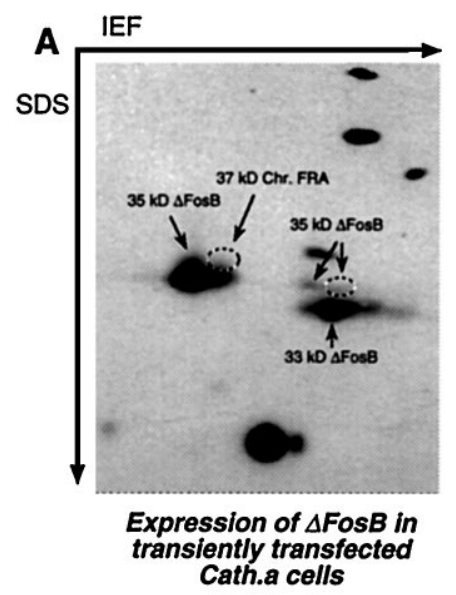

B

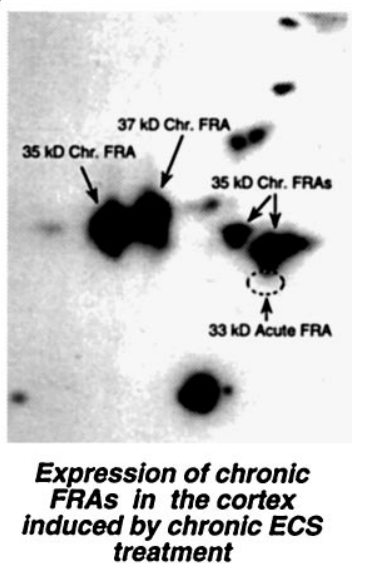

C

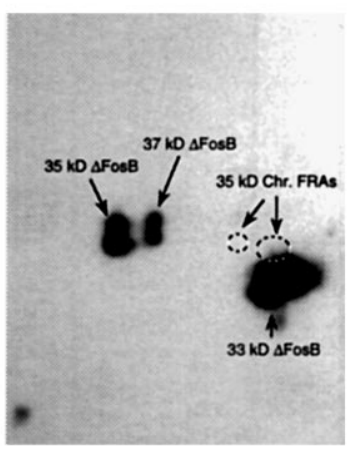

Expression of $\triangle F o s B$ in stable transfected $\mathrm{C} 6$ cells that the chronic FRAs correspond precisely with the 35 and 37 $\mathrm{kDa} \Delta$ FosB proteins. The $35 \mathrm{kDa}$ chronic FRA migrated on two-dimensional gels as two to three widely spaced bands that correspond to the positions of $35 \mathrm{kDa} \Delta \mathrm{FosB}$ protein bands, whereas the $37 \mathrm{kDa}$ chronic FRA corresponds to the position of the $37 \mathrm{kDa} \Delta$ FosB protein. In contrast, the $33 \mathrm{kDa} \Delta$ FosB protein migrated at the same position as a $33 \mathrm{kDa}$ FRA induced in the brain by acute ECS or cocaine treatment (Chen et al., 1995). Another observation from these studies, as mentioned above, is that levels of the $37 \mathrm{kDa} \Delta$ FosB protein are barely detectable in the transiently transfected cells and that, even in the stably transfected cells, only a relatively small amount of the $37 \mathrm{kDa} \Delta$ FosB was detected (see Figs. 1, 2). These results suggest that the accumulation of the $37 \mathrm{kDa}$ protein in vitro may be slower than the more robust accumulation of the $37 \mathrm{kDa}$ chronic FRA in the brain after chronic perturbation.

It should be noted that there was one major protein of $\sim 42$ $\mathrm{kDa}$, detected by the anti-FRA antibody, in the untransfected and FosB-transfected cells (Figs. 1, 2). This band was not recognized by either the anti-FosB(N) or anti-FosB(C) antibody. Interestingly, expression of this endogenous $42 \mathrm{kDa}$ FRA (which could be FRA-2) was repressed in the $\Delta$ FosB-transfected cells. This suggests the possibility that the $\Delta$ FosB proteins are functional and serve as negative regulators of the expression of this protein.

The 33,35 , and $37 \mathrm{kDa} \triangle F o s B$ proteins are isoforms of the same gene product

Analysis of the $\Delta$ FosB cDNA sequence reveals that there are four AUG start codons in the $\Delta$ FosB mRNA, of which the first AUG locates in the first exon and the other three AUGs locate in the second exon (Fig. 4A). Based on this sequence information, we hypothesized that the multiple $\Delta$ FosB proteins expressed from $\Delta$ FosB cDNA (i.e., the 37, 35, 33, 29, and $28 \mathrm{kDa}$ bands in Figs. $1,2)$ are alternative translation products from different translation start sites. To test the hypothesis, we deleted the first AUG, or both the first and second AUGs, from the $\triangle$ FosB cDNA and analyzed the expression patterns of the deletion mutants in transiently transfected CATH.a cells (Fig. 4B). Contrary to our hypothesis, we found that the 33,35 , and $37 \mathrm{kDa}$ protein bands disappeared when the first AUG was deleted and that further deletion of the second AUG did not eliminate more bands, namely, the 28 and $29 \mathrm{kDa}$ proteins.
A

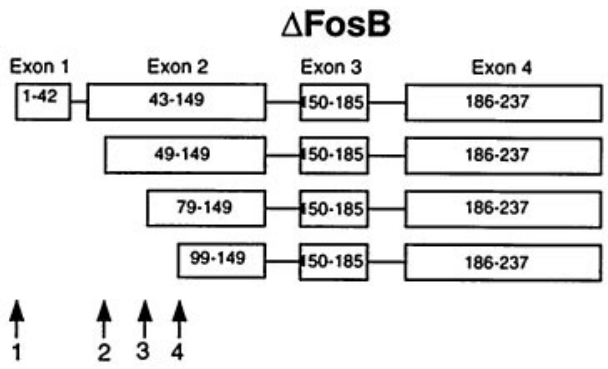

B

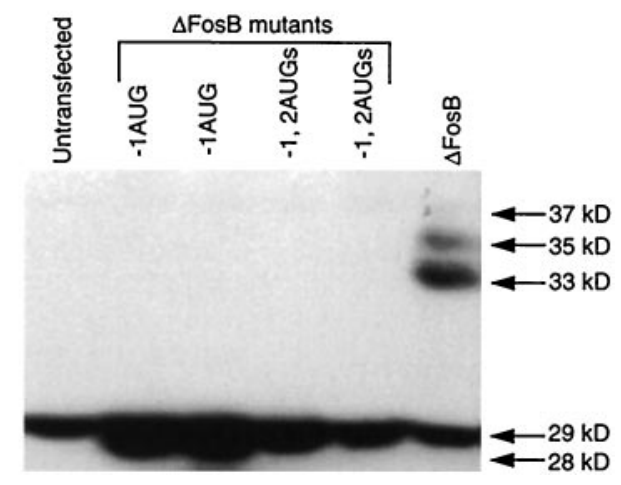

Figure 4. Analysis of translation start sites for $\Delta$ FosB-derived proteins. $A$, Genomic map for $\triangle F$ FosB and the location of four alternative start (AUG) codons present in the resulting mRNA. $B$, Western blot of extracts of CATH.a cells transiently transfected with full-length $\triangle$ FosB cDNA or with mutants lacking the first $(-1 A U G)$ or the first and second $(-1,2 A U G s)$ start codons. Note that deletion of the first AUG completely obliterated the 37,35 , and $33 \mathrm{kDa} \Delta$ FosB proteins, whereas deletion of the first and second AUGs did not abolish the $28-29 \mathrm{kDa} \Delta \mathrm{FosB}$ proteins, as indicated by the still higher levels of immunoreactivity present in this region of the gel compared with that in untransfected cells. The results shown are representative of three separate determinations.

These results indicate that the 33,35 , and $37 \mathrm{kDa} \Delta \mathrm{FosB}$ proteins are encoded by the same open reading frame of the $\triangle$ FosB mRNA and that they are isoforms of one another. In contrast, the 28 and $29 \mathrm{kDa} \Delta$ FosB proteins seem to be translated from start codon(s) downstream of the second AUG, although we 
cannot rule out the possibility that deletion of the first AUGs altered the use of the downstream ones. Because FosB and $\Delta$ FosB mRNAs contain identical exons 1 and 2, it would be expected that FosB mRNA would encode a similar pattern of protein products, namely products from the first AUG and smaller products from the downstream AUG. Indeed, deletion studies confirm that the $35 \mathrm{kDa}$ FosB protein (see Figs. 1, 2) is translated from a downstream start codon (data not shown).

\section{The 35 and $37 \mathrm{kDa} \Delta \mathrm{FosB}$ proteins are highly stable}

Previous work has shown that the stability of FosB and $\Delta$ FosB mRNAs are similar, with both returning to control levels within a few hours of acute ECS or cocaine treatment (Chen et al., 1995). Moreover, the two mRNAs show a reduced ability to be induced after repeated treatment. This is in contrast to the gradual accumulation of the chronic FRAs during a course of chronic treatment. One possible explanation for these findings is that the chronic FRAs, once induced, are relatively stable proteins. To test this possibility directly, we compared the stability of $\Delta$ FosB and FosB proteins using transfected cells in which $\Delta$ FosB or FosB expression is under the control of the tetracycline-regulated gene expression system. It was necessary to use such an inducible expression system, in which the expression of proteins can be turned on and off, to assess protein stability, in contrast to a constitutive system in which the expression of proteins is always on and would therefore interfere with measures of protein turnover.

In the tetracycline system (Shockett et al., 1995), $\Delta$ FosB and FosB cDNAs were placed under the control of a promoter consisting of the tetracycline operator (Tetop) and minimal CMV promoter, as shown in Figure $5 A$. In the absence of tetracycline, tTA binds to the promoter and activates the transcription of the $\Delta$ FosB and FosB cDNAs. In the presence of tetracycline, tTA undergoes a conformational change and cannot bind to the Tetop promoter, so that transcription of FosB and $\Delta$ FosB is inhibited. In this manner, the expression of FosB and $\Delta$ FosB proteins can be activated or repressed, respectively, by the absence or presence of tetracycline.

The tetracycline system was first used to encode FosB and $\Delta$ FosB transcription in transiently transfected CATH.a cells. The transfected cells were cultured in the absence of tetracycline for $24 \mathrm{hr}$, after which time tetracycline was added to the culture medium to turn off transcription of $\Delta$ FosB and FosB cDNAs (Fig. $5 B)$. As shown in Figure $5 B$, levels of $\Delta$ FosB and FosB proteins decreased in the cells as the proteins were degraded. It was found that the $\Delta$ FosB proteins were more stable than the FosB proteins. Note, for example, in Figure $5 B$ that levels of all FosB products were at barely detectable levels $2 \mathrm{~d}$ after addition of tetracycline, whereas the $\Delta$ FosB proteins remained at much higher levels. This impression is verified by quantitative analysis of the data. For example, Figure $5 C$ shows a comparison of the rate of disappearance of the $35 \mathrm{kDa} \Delta \mathrm{FosB}$ protein and the $46 \mathrm{kDa}$ FosB protein. Note that because only $\sim 10 \%$ of the cells were transfected in these transient transfection experiments, and expression of $\Delta \mathrm{FosB}$ was permitted for a relatively short time only ( $24 \mathrm{hr}$ ), no $37 \mathrm{kDa}$ $\Delta$ FosB protein was detected.

To overcome this limitation of transient transfections, and thereby to study the stability of the $37 \mathrm{kDa} \Delta$ FosB protein, we made stable C6 glioma cell lines transfected with the FosB and $\Delta$ FosB cDNAs under the control of the tetracycline-regulated promoter. The use of these cell lines, in which expression of $\Delta$ FosB can be turned on and off in repeated cycles of tetracycline exposure and withdrawal, is shown in Figure 6. These initial
A

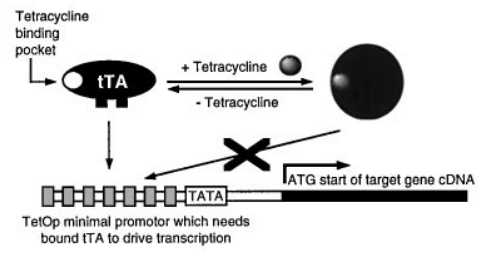

B

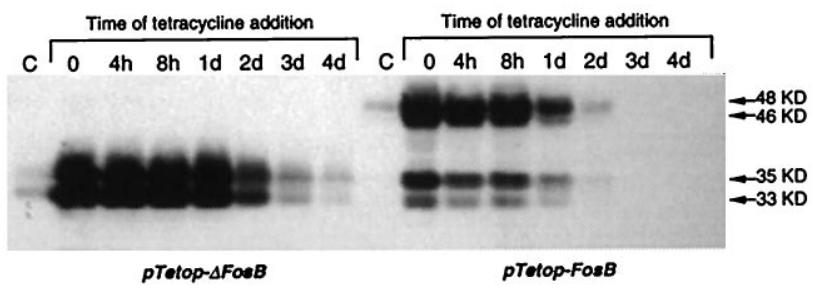

C

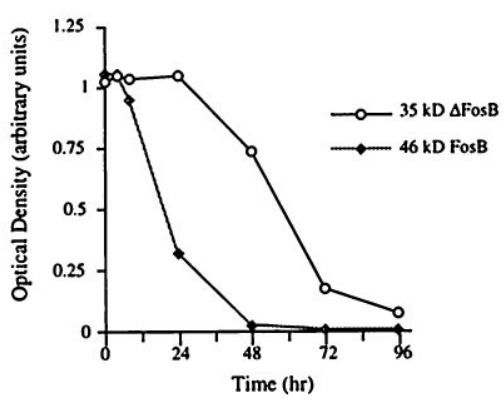

Figure 5. Analysis of the stability of $\Delta$ FosB and FosB proteins in CATH.a cells transiently transfected with $\Delta$ FosB or FosB cDNA under the control of the tetracycline expression system. $A$, Schematic illustration of the tetracycline-regulated gene expression system, as adapted from Dr. Rene Hen (Columbia University, Neuroscience Short Course, Society for Neuroscience, 1996). $B$, Western blot of $\Delta$ FosB and FosB proteins in CATH.a cells $24 \mathrm{hr}$ after transfection (time 0 ) and at varying times after the addition of tetracycline ( $4 \mathrm{hr}-4 \mathrm{~d})$ to turn off expression. $C$, Quantitative representation of the time-dependent reduction in the $35 \mathrm{kDa} \Delta$ FosB protein and the $46 \mathrm{kDa}$ FosB protein after the addition of tetracycline. The results shown are representative of two separate determinations.

experiments indicated that the $37 \mathrm{kDa} \Delta \mathrm{FosB}$ protein appears at significant levels only in cells in which the expression of $\Delta$ FosB cDNA is turned on for relatively long periods.

To compare the stability of the 33,35 , and $37 \mathrm{kDa} \Delta \mathrm{FosB}$ proteins, we cultured the $\Delta$ FosB stable cell lines in the absence or presence of tetracycline for varying periods. The results of this experiment are shown in Figure 7. When the cells were cultured in the absence of tetracycline for $11 \mathrm{~d}$, the $37 \mathrm{kDa}$ protein accumulated to a significant level, approximately comparable to that of the 33 and $35 \mathrm{kDa} \Delta \mathrm{FosB}$ proteins (Fig. 7, lane 1). In contrast, when the cells were cultured first in the absence of tetracycline for $5 \mathrm{~d}$ and then in the presence of tetracycline for $6 \mathrm{~d}$, the 35 and 37 $\mathrm{kDa}$ proteins were detectable at low levels, whereas the $33 \mathrm{kDa}$ protein was not detectable (Fig. 7, lane 2). This suggests that the 35 and $37 \mathrm{kDa}$ proteins are more stable than the $33 \mathrm{kDa}$ protein. When $\Delta$ FosB expression was on for $5 \mathrm{~d}$, then switched off for $3 \mathrm{~d}$ and back on for $3 \mathrm{~d}$, the first new $\Delta$ FosB protein detected was the $33 \mathrm{kDa}$ protein (Fig. 7, lane 3). This suggests that the $33 \mathrm{kDa}$ protein is the native form of $\Delta \mathrm{FosB}$, that is, the first expressed. When $\Delta$ FosB expression was on for $8 \mathrm{~d}$ and then turned off for $3 \mathrm{~d}$, the $33 \mathrm{kDa}$ protein was not detectable, whereas the 35 and $37 \mathrm{kDa}$ proteins remained (Fig. 7, lane 4 ). This suggests, again, that the 35 
A

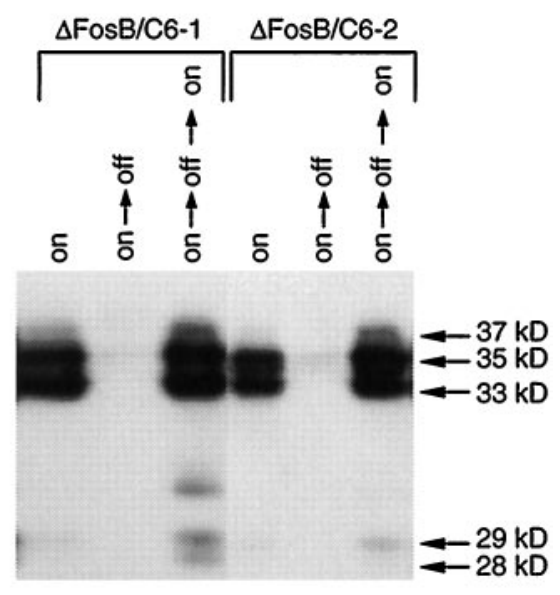

B

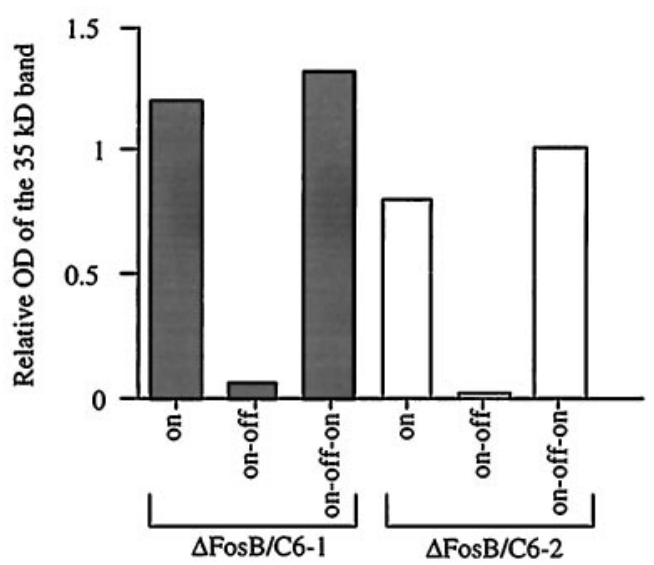

Figure 6. Western blots showing the expression of $\Delta$ FosB proteins in C6 glioma cells stably transfected with $\triangle$ FosB cDNA under the control of the tetracycline expression system. $A$, Western blot analysis, using the panFRA antibody, of extracts of stable C6 glioma cell lines. $B$, Quantitative representation of the Western blots. Results from two independent stable cell lines are shown. One set of cells was harvested after being cultured for $3 \mathrm{~d}$ in the absence of tetracycline to turn $\Delta \mathrm{FosB}$ expression on (on); a second set of cells was harvested after being cultured for $3 \mathrm{~d}$ in the absence of tetracycline, followed by $1 \mathrm{wk}$ in the presence of tetracycline to turn $\Delta$ FosB expression off (on $\rightarrow$ off); a third set of cells was harvested after being cultured for $3 \mathrm{~d}$ in the absence of tetracycline, followed by $1 \mathrm{wk}$ in the presence of tetracycline and then $1 \mathrm{wk}$ in the absence of tetracycline to turn $\Delta$ FosB expression back on (on $\rightarrow$ off $\rightarrow$ on ). Note the ability to turn $\Delta$ FosB expression repeatedly on and off by use of the tetracycline expression system. Note also that the $37 \mathrm{kDa} \Delta$ FosB protein appears appreciably only after more prolonged periods of expression (i.e., in the on $\rightarrow$ off $\rightarrow$ on condition). The results shown are representative of two separate determinations of six independent cell lines examined.

and $37 \mathrm{kDa}$ proteins are more stable than the $33 \mathrm{kDa}$ protein and are presumably derived from the $33 \mathrm{kDa}$ protein via some form of covalent modification.

A quantitative analysis of the stability of $\Delta$ FosB and FosB proteins was performed by culturing cells in the absence of tetracycline for $11 \mathrm{~d}$ and harvesting them at varying times after the addition of tetracycline (Fig. 8). In this analysis the $33 \mathrm{kDa} \Delta \mathrm{FosB}$ protein and the FosB-derived proteins showed relatively short half-lives of $9-10 \mathrm{hr}$. This short half-life is consistent with the highly transient appearance of these proteins in the brain in vivo after acute ECS or cocaine treatment (Hope et al., 1994a,b; Chen et al., 1995). In contrast, the 35 and $37 \mathrm{kDa} \Delta$ FosB proteins

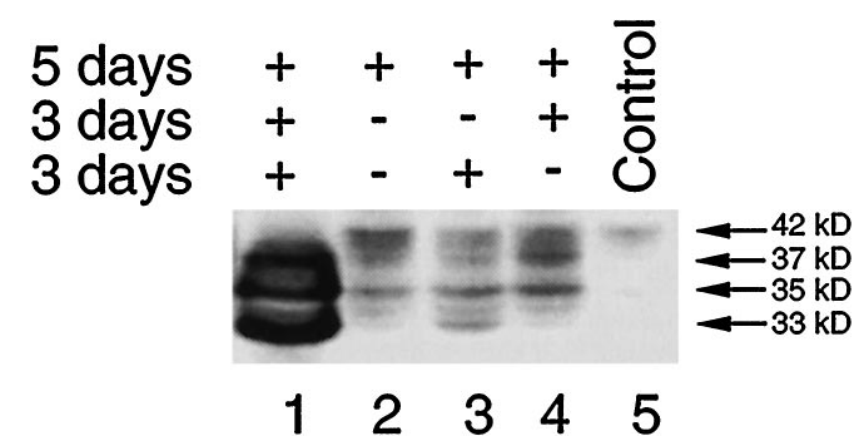

Figure 7. Western blot showing the relative stability of the 37,35 , and 33 $\mathrm{kDa} \Delta$ FosB proteins in stable C6 glioma cells transfected with $\Delta$ FosB cDNA under the control of the tetracycline expression system. Cells were grown for varying times in the absence or presence of tetracycline to turn $\Delta \mathrm{FosB}$ expression on $(+)$ or off $(-)$, respectively, and cell extracts were then analyzed by Western blotting using the pan-FRA antibody. In lane 1, cells were harvested after being grown in the absence of tetracycline for $11 \mathrm{~d}$. In lane 2, cells were harvested after being grown in the absence of tetracycline for $5 \mathrm{~d}$, followed by an additional $6 \mathrm{~d}$ in the presence of tetracycline. In lane 3, cells were harvested after being grown in the absence of tetracycline for $5 \mathrm{~d}$, followed by $3 \mathrm{~d}$ in the presence of tetracycline and another $3 \mathrm{~d}$ in the absence of tetracycline. In lane 4, cells were harvested after being grown in the absence of tetracycline for $8 \mathrm{~d}$, followed by an additional $3 \mathrm{~d}$ in the presence of tetracycline. Control (untransfected) cells are shown for comparison and illustrate the presence of an endogenous FRA, possibly FRA-2, of $\sim 42 \mathrm{kDa}$ (see also Fig. 1). The results demonstrate that the $33 \mathrm{kDa} \Delta$ FosB protein is the first to appear after activation of $\Delta$ FosB expression, but this protein is less stable compared with the 35 and $37 \mathrm{kDa} \Delta \mathrm{FosB}$ proteins. The results shown are representative of three separate determinations using two independent, stable cell lines.

showed longer half-lives. The $35 \mathrm{kDa}$ protein decayed with an estimated half-life of $28 \mathrm{hr}$, and the $37 \mathrm{kDa}$ protein decayed with an estimated half-life of $208 \mathrm{hr}$. This dramatic stability of the 37 $\mathrm{kDa}$ protein of $>8 \mathrm{~d}$ in vitro is comparable to the half-life of $7 \mathrm{~d}$ calculated for the chronic FRAs in vivo after chronic administration of ECSs or cocaine (Hope et al., 1994b).

\section{Transcriptional activity of $\Delta F o s B$ and FosB proteins}

To study the function of $\Delta$ FosB and FosB proteins, we first analyzed their DNA-binding activity. As shown in Figure $9 A$, expression of $\Delta$ FosB proteins was associated with the appearance of high levels of AP-1 binding. The AP-1 complex so formed migrated at the same position as the chronic AP-1 complex induced in the brain by chronic ECS treatment. Expression of FosB proteins was also associated with high levels of AP-1 binding, but the AP-1 complex comigrated in this case with the upper, acute AP-1 complex induced in brain by acute ECS treatment (Fig. 9B). These results demonstrate that the $\Delta$ FosB proteins exhibit DNA-binding activity. Moreover, the $\Delta$ FosB-AP-1 complex seems to be identical to the chronic AP-1 complex induced in brain by chronic ECS or cocaine treatment (Hope et al., 1994a,b).

To test whether $\Delta$ FosB proteins can regulate the activity of promoters containing AP-1 sites, we transiently transfected $\mathrm{SH}$ SY5Y cells with $\Delta$ FosB (in the tetracycline expression system) and with the $4 \times \mathrm{AP}-1 / \mathrm{RSV}$-Luc plasmid (a construct that contains four tandem consensus AP-1 sites driving expression of a luciferase reporter gene). Analysis of luciferase activity (Fig. 10 A) showed that AP-1 promoter activity was upregulated to a small extent by $\Delta$ FosB. This transactivation activity of $\Delta$ FosB on the AP-1 promoter was confirmed in stable $\Delta$ FosB-transfected C6 cells, which showed a dramatic induction of luciferase activity in response to $\Delta$ FosB expression (Fig. $10 B$ ). In contrast to $\Delta$ FosB, 


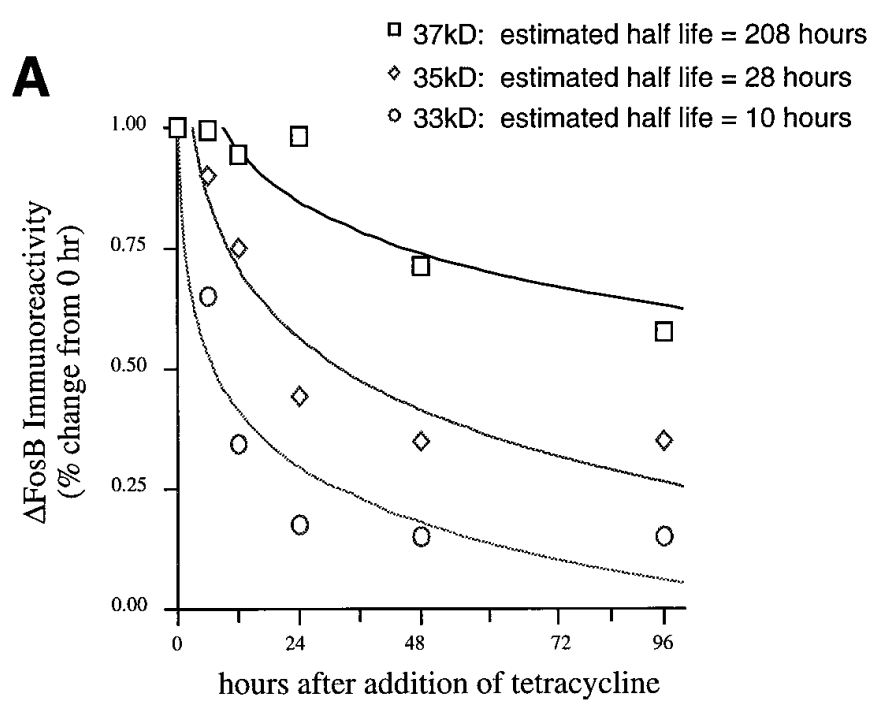

B

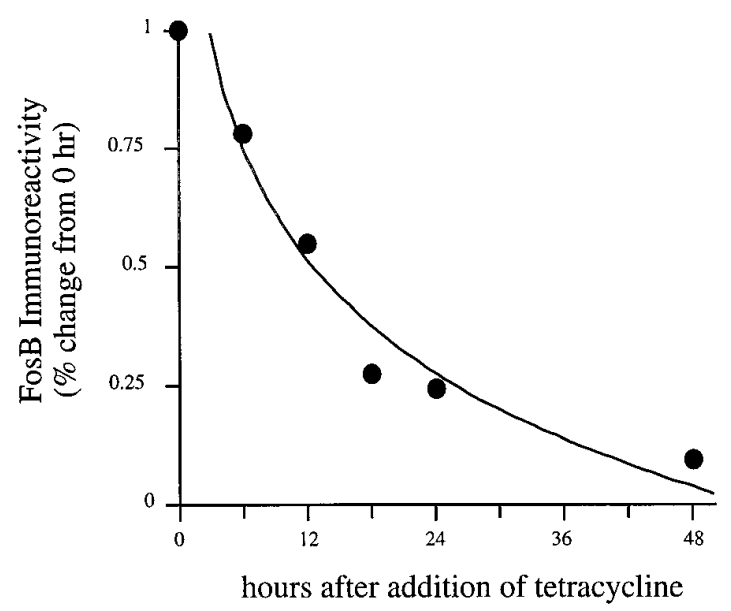

Figure 8. Analysis of the stability of $\Delta \mathrm{FosB}$ and FosB proteins in stable C6 glioma cells transfected with $\Delta$ FosB or FosB cDNAs under the control of the tetracycline expression system. Cells were grown in the absence of tetracycline for $11 \mathrm{~d}$ to turn $\Delta \mathrm{FosB}(A)$ or FosB $(B)$ expression on, after which time the cells were cultured in the presence of tetracycline for varying periods to turn expression off. The results demonstrate the dramatic stability of the $37 \mathrm{kDa} \Delta$ FosB protein compared with the other $\Delta \mathrm{FosB}$ and FosB proteins. The results shown are representative of two separate determinations using two independent, stable cell lines.

FosB downregulated the activity of the promoter; this is illustrated in Figure $10 C$, which shows a decrease in luciferase activity in stable FosB-transfected C6 cells after FosB expression. Tetracycline itself exerted no effect on AP-1 promoter activity in SH-SY5Y or C6 cells that lack FosB and $\Delta$ FosB plasmids, which excludes the possibility of a tetracycline artifact (data not shown).

\section{DISCUSSION}

The major finding of this study is that the 35 and $37 \mathrm{kDa}$ chronic FRAs, induced in the brain by a variety of chronic treatments (see introductory remarks), are the stable products of $\Delta$ FosB. We detected five proteins generated from $\triangle$ FosB cDNA, of which the 33 , 35 , and $37 \mathrm{kDa}$ proteins are isoforms. The $33 \mathrm{kDa}$ protein is the first to appear after induction of $\Delta$ FosB expression, with the other forms presumably generated by covalent modification. The 35 and partic-

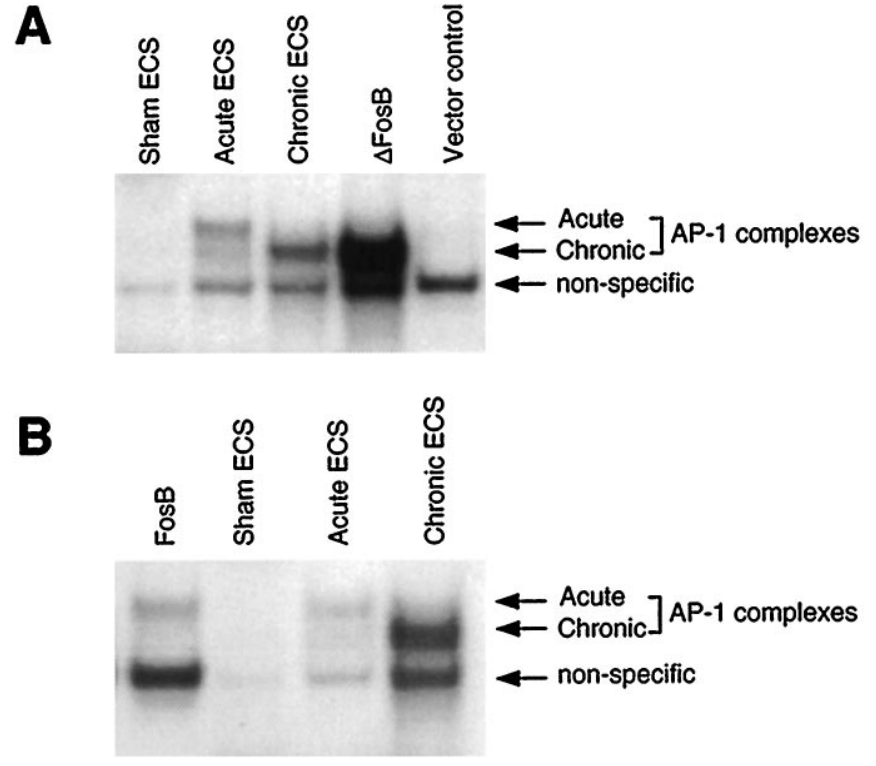

Figure 9. Gel shift assays showing the induction of AP-1 DNA-binding activity after the expression of $\Delta$ FosB or FosB in stable C6 glioma cells. Extracts of a stable cell line that allows constitutive expression of $\Delta \mathrm{FosB}$ $(A)$ or FosB $(B)$ cDNA and of cells transfected with vector DNA only (Vector control) were analyzed for AP-1 DNA-binding activity using gel shift assays. Extracts of cerebral cortex from rats that were treated acutely or chronically with ECSs, or with sham treatments, were analyzed for comparison. As shown in $A$, the expression of $\Delta$ FosB results in the dramatic induction of an AP-1 complex that comigrates with the AP-1 complex induced by chronic, but not acute, ECSs. In contrast, as shown in $B$, the expression of FosB results in the induction of an AP-1 complex that comigrates with the AP-1 complex induced in brain by acute ECS. The results shown are representative of three separate determinations.

ularly the $37 \mathrm{kDa}$ isoforms are more stable than the $33 \mathrm{kDa}$ isoform, which provides the probable mechanism for the accumulation of the 35 and $37 \mathrm{kDa}$ chronic FRAs in the brain after repeated perturbations. Accumulation of the $37 \mathrm{kDa} \Delta \mathrm{FosB}$ occurs very slowly in vitro, but the stability of this protein is highest among the $\Delta$ FosB isoforms, which could explain how both the 35 and $37 \mathrm{kDa}$ proteins reach similar levels in vivo after chronic treatments. Together, these findings provide direct support for our earlier working hypothesis (Hope et al. 1994b) that proposed the slow accumulation of stable chronic FRAs by repeated treatments.

Recently, fos $B$ knock-out mice were developed (Brown et al., 1996). Induction of the 35 and $37 \mathrm{kDa}$ chronic FRAs was completely absent after repeated ECS or cocaine treatment in the -/- mutant mice, as opposed to the robust induction seen in $+/+$ wild-type mice (Hiroi et al., 1996, 1997). Although the knock-out disrupts both FosB and $\Delta$ FosB mRNAs, information from the knock-out mice provides strong confirmation of the conclusions of the current study that the chronic FRAs are $\Delta$ FosB proteins.

Previous work has shown that FosB and $\Delta$ FosB mRNAs have similar stability, as revealed by RNase protection analysis (Chen et al., 1995). Both mRNAs are induced rapidly and transiently by acute cocaine or ECS treatment, which is consistent with the properties of $\operatorname{fos} B$ as an immediate early gene. However, in addition to the unstable protein products of the gene (i.e., the 33 $\mathrm{kDa} \Delta$ FosB and all FosB proteins), $\Delta$ FosB mRNA gives rise to products (i.e., the 35 and $37 \mathrm{kDa}$ proteins) that are relatively stable. Indeed, the $37 \mathrm{kDa}$ protein exhibits an estimated half-life that is far longer than that of other immediate early gene products. This explains how the 35 and $37 \mathrm{kDa}$ proteins accumulate in 
A

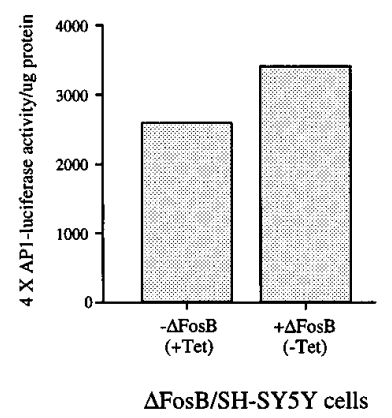

B

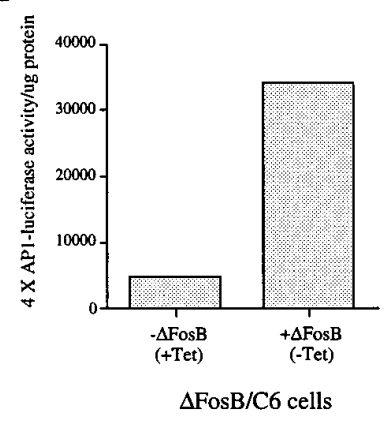

C

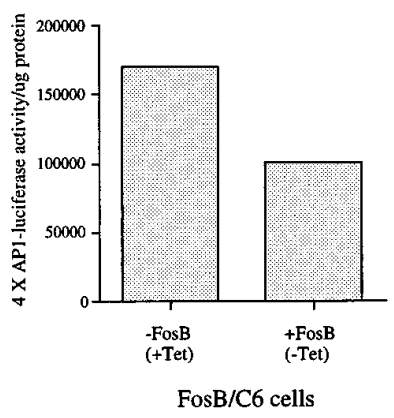

Figure 10. Analysis of the transactivating properties of $\Delta$ FosB and FosB proteins in SH-SY5Y and C6 glioma cells. $A$, Results from SH-SY5Y cells transiently transfected with $\triangle$ FosB cDNA under the control of the tetracycline expression system. $B, C$, Results from C6 glioma cells stably transfected with $\triangle$ FosB and FosB, respectively, under the control of the tetracycline expression system. Both types of cells were also transiently transfected with $4 \times$ AP-1/RSV-Luc, which contains a promoter of four tandem consensus AP-1 sites driving the expression of a luciferase reporter gene. The results demonstrate the ability of $\Delta$ FosB to upregulate AP-1 promoter activity in both cell lines. In contrast, FosB downregulates AP-1 promoter activity in the C6 cells. The results shown are representative of three separate determinations.

Table 1. Potential PEST sequences in the full-length FosB and $\triangle$ FosB proteins

\begin{tabular}{|c|c|c|c|}
\hline Protein & PEST sequence & $\begin{array}{l}\text { Amino acid } \\
\text { location of } \\
\text { PEST sequence }\end{array}$ & $\begin{array}{l}\text { PEST- } \\
\text { FIND } \\
\text { score }\end{array}$ \\
\hline FosB $/ \Delta$ FosB & $\begin{array}{l}\text { 1. RCSSSPSAESQYLSSVDSFGSPPTAAASQECAGLGEMPGSFVPT } \\
\text { VTAITTSQDLQWLVQPTLISSMAQSQGQPLASQPPAVDPYAMPGTS } \\
\text { STPGLSAYSTGGASGSGGPSTSTTTSGPVSAR }\end{array}$ & $14-136$ & 2.832 \\
\hline & 2. REETLTPEEEEK & $146-157$ & 23.004 \\
\hline FosB & $\begin{array}{l}\text { 3. KEDGFGWLLPPPPPPPLPFQSSR } \\
\text { 4. RTSGSEQPSDPLNSPSLLAL }\end{array}$ & $\begin{array}{l}248-270 \\
319-338\end{array}$ & $\begin{array}{l}0.565 \\
1.365\end{array}$ \\
\hline
\end{tabular}

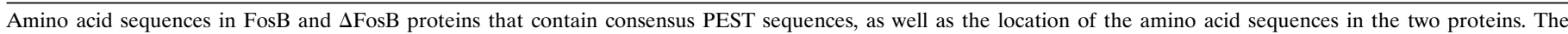
PEST-FIND score provides a measure of the predicted activity of the consensus sites; the larger the score, the greater the predicted activity.

the brain after chronic treatments when levels of $\triangle$ FosB mRNA are low. Moreover, these results suggest that the fos $B$ gene is an atypical immediate early gene, in that it generates unstable protein products in response to a single acute stimulation and stable products in response to repeated stimulations. The stable products can be viewed in two ways from a functional point of view. They could exert the same transcriptional effect as the unstable products and thereby play a role in saving "energy" for the cell as it responds in the same way to repeated stimulations. Alternatively, they could exert the opposite transcriptional effect as the unstable products and thereby play a negative feedback role in opposing further responses to the stimulations. Of course, these possibilities are not mutually exclusive, in that the chronic FRAs could play both roles, depending on the various target genes in question and the Jun family member with which they form functional AP-1 complexes.

The mechanism responsible for the stability of the 35 and 37 $\mathrm{kDa} \Delta$ FosB proteins remains unknown. For some immediate early genes, such as c-fos and $m y c$, the encoded proteins contain several potential PEST (P, proline; E, glutamatic acid; $\mathrm{S}$, serine; and $\mathrm{T}$, threonine) sequences, which are correlated with fast protein degradation (Rogers et al., 1986). Computer analysis of FosB and $\triangle$ FosB amino acid sequences by the PESTFIND program (Rechsteiner and Rogers, 1996) revealed four potential PEST sequences in FosB and two potential PEST sequences in $\Delta$ FosB (Table 1). The fact that the 35 and $37 \mathrm{kDa}$ $\Delta$ FosB proteins are more stable than FosB proteins may be attributable to the smaller number of PEST sequences in their amino acid sequences. However, the PEST sequences alone cannot explain the stability of these proteins, because the 33 $\mathrm{kDa} \triangle \mathrm{FosB}$ protein also contains only two PEST sequences. Rather, it would seem that the $33 \mathrm{kDa}$ protein is modified in some way to result in the 35 and $37 \mathrm{kDa}$ proteins and that this modification is important for stabilization of these proteins. A potential role for phosphorylation in generating the 35 and 37 $\mathrm{kDa}$ isoforms is currently under investigation.

Accumulation of $\Delta$ FosB isoforms would be expected to have an important impact on brain function, because we show that these proteins exhibit AP-1 DNA-binding activity and can regulate the activity of a promoter containing AP-1 sites in a reporter gene assay. Such an important role for $\Delta$ FosB proteins is supported by studies of $\operatorname{fos} B$ knock-out mice, which exhibit impaired behavioral plasticity to chronic ECS and cocaine treatments (Hiroi et al., 1996; Hiroi, Brown, Haile, Hong, Greenberg, and Nestler, unpublished observations). Numerous neural genes are known to contain AP-1 sites in their promoter regions (see Morgan and Curran, 1991; Chen et al., 1995). Work is now needed to identify which of these putative target genes are regulated by the stable $\Delta$ FosB isoforms that are induced in specific brain regions by chronic treatments and that are ultimately responsible for the resulting behavioral plasticity. Although further research is needed to delineate the precise mechanisms involved, the long-lasting nature of the stable $\Delta$ FosB proteins make them attractive candidate molecules to mediate some of the long-term adaptive changes in the brain associated with a variety of chronic perturbations. 


\section{REFERENCES}

Biedler JL, Roffler-Tarlov S, Schachner M, Freedman LS (1978) Multiple neurotransmitter synthesis by human blastoma cell lines and clones. Cancer Res 38:3751-3757.

Brown JR, Ye H, Bronson RT, Dikkes P, Greenberg ME (1996) A defect in nurturing in mice lacking the immediate early gene fosB. Cell 86:297-309.

Campeau S, Hayward MD, Hope B, Rosen JB, Nestler EJ, Davis M (1991) Induction of c-fos proto-oncogene in rat amygdala during unconditioned and conditioned fear. Brain Res 565:349-352.

Chen J, Nye HE, Kelz MB, Hiroi N, Nakabeppu Y, Hope BT, Nestler EJ (1995) Regulation of dFosB and FosB-like proteins by electroconvulsive seizure and cocaine treatments. Mol Pharmacol 48:880-889.

Doucet JP, Nakabeppu Y, Bedard PJ, Hope BT, Nestler EJ, Jasmin BJ, Chen JS, Iadarola MJ, St-Jean M, Wigle N, Planchet P, Grondin R, Robertson GS (1996) Chronic alterations in dopaminergic neurotransmission produce a persistent elevation of dFosB-like protein(s) in both the rodent and primate striatum. Eur J Neurosci 8:365-381.

Hiroi N, Brown JR, Haile CN, Greenberg ME, Nestler EJ (1996) FosB "knockout" mice: loss of chronic FRAs and abnormalities in cocaineregulated behavior. Soc Neurosci Abstr 22:386.

Hiroi N, Brown JR, Ye H, Saudou F, Vaidya VA, Charlton M, Duman RS, Greenberg ME, Nestler EJ (1997) Essential role of the fosB gene in chronic actions of electroconvulsive seizures: regulation of NMDA receptor subunit expression and tolerance to motor seizure. Soc Neurosci Abstr, in press.

Hope BT, Kosofsky B, Hyman S, Nestler EJ (1992) Regulation of immediate early gene expression and AP-1 binding in the rat nucleus accumbens by chronic cocaine. Proc Natl Acad Sci USA 89:5764-5768.

Hope BT, Kelz MB, Duman RS, Nestler EJ (1994a) Chronic electroconvulsive seizure (ECS) treatment results in expression of a long-lasting AP-1 complex in brain with altered composition and characteristics. J Neurosci 14:4318-4328.

Hope BT, Nye HE, Kelz MB, Self DW, Iadarola M, Nakabeppu Y, Duman RS, Nestler EJ (1994b) Induction of a long-lasting AP-1 complex composed of altered Fos-like proteins in brain by chronic cocaine and other chronic treatments. Neuron 13:1235-1244.

Hyman SE, Nestler EJ (1996) Initiation and adaptation: a paradigm for understanding psychotropic drug action. Am J Psychiatry 153:151-162.

Jian M, Staines WA, Iadarola MJ, Robertson GS (1993) Destruction of the nigrostriatal pathway increases Fos-like immunoreactivity predominantly in striatopallidal neurons. Mol Brain Res 19:156-160.

Kasof GM, Mandelzys A, Maika SD, Hammer RE, Curran T, Morgan JI (1995) Kainic acid-induced neuronal death is associated with DNA damage and a unique immediate-early gene response in c-fos-lacZ transgenic rats. J Neurosci 15:4238-4249.

Korner M, Rattner A, Mauxion F, Sen R, Citri Y (1989) A brain-specific transcription factor. Neuron 3:563-592.
Moratalla R, Elibol B, Vallejo M, Graybial AM (1996) Network-level changes in expression of inducible Fos-Jun proteins in the striatum during chronic cocaine treatment and withdrawal. Neuron 17:147-156.

Morgan JI, Curran T (1991) Stimulus-transcription coupling in the nervous system: involvement of the inducible proto-oncogenes fos and jun. Annu Rev Neurosci 14:421-451.

Morgan JI, Curran T (1995) Immediate-early genes: ten years on. Trends Neurosci 18:66-67.

Nakabeppu Y, Nathans D (1991) A naturally occurring truncated form of fosB that inhibits Fos/Jun transcriptional activity. Cell 64:751-759.

Nakabeppu Y, Oda S, Sekiguchi M (1993) Proliferative activation of quiescent rat-1A cells by FosB. Mol Cell Biol 13:4157-4166.

Nye HE, Hope BT, Kelz MB, Iadarola MJ, Nestler EJ (1995) Pharmacological studies of the regulation of chronic Fos-related antigen induction by cocaine in striatum and nucleus accumbens. J Pharmacol Exp Ther 275:1671-1680.

Nye HE, Nestler EJ (1996) Induction of chronic Fras (Fos-related antigens) in rat brain by chronic morphine administration. Mol Pharmacol 49:636-645.

Pennypacker KR, Thai L, Hong JS, McMillian MK (1994) Prolonged expression of AP-1 transcription factors in the rat hippocampus after systemic kainate treatment. J Neurosci 14:3998-4006.

Pennypacker KR, Hong JS, McMillian MK (1995) Implications of prolonged expression of Fos-related antigens. Trends Pharmacol Sci 16:317-321.

Pich EM, Pagliusi SR, Tessari M, Talabot-Ayer D, Hooft van Huijsduijnen R, Chiamulera C (1997) Common neural substrates for the addictive properties of nicotine and cocaine. Science 275:83-86.

Rechsteiner M, Rogers SW (1996) PEST sequences and regulation by proteolysis. Trends Biochem Sci 21:261-271.

Rogers S, Wells R, Rechsteiner M (1986) Amino acid sequences common to rapidly degraded proteins: the PEST hypothesis. Science 234: 364-368.

Sharp FR, Sagar SM, Hicks K, Lowenstein D, Hisanaga K (1991) c-Fos mRNA, Fos, and Fos-related antigen induction by hypotonic saline and stress. J Neurosci 11:2321-2331.

Shockett P, Difilippantonio M, Hellman N, Schatz DG (1995) A modified tetracycline-regulated system provides autoregulatory, inducible gene expression in cultured cells and transgenic mice. Proc Natl Acad Sci USA 92:6522-6526.

Suri C, Fung BP, Tischler AS, Chikaraishi DM (1993) Catecholaminergic cell lines from the brain and adrenal glands of tyrosine hydroxylaseSV40 T antigen transgenic mice. J Neurosci 13:1280-1291.

Zerial M, Toschi L, Ryseck R-P, Schuermann Muller R, Bravo R (1989) The product of a novel growth factor activated gene, fosB, interacts with Jun proteins enhancing their DNA binding activity. EMBO J 8:805-813. 